\title{
Evaluasi Program Keluarga Harapan dalam Meningkatkan Keberdayaan Perempuan di Bidang Pendidikan Dan Kesehatan
}

\section{Evaluating Program Keluarga Harapan (Pkh) In Improving Women Empowerment On Education And Health}

\author{
Rina Gaguk Ika Prayitna, Ismi Dwi Astuti Nurhaeni, Argyo Demartoto \\ Program Studi Magister Administrasi Publik \\ Fakultas Ilmu Sosial Dan Politik Universitas Sebelas Maret Surakarta \\ Gaguk789@gmail.com
}

\begin{abstract}
Abstrak
Penelitian ini membahas implementasi dan upaya peningkatan keberdayaan perempuan yang dilakukan oleh Program Keluarga Harapan (PKH) sebagai salah satu program penanggulangan kemiskinan di Kabupaten Ponorogo. Kabupaten Ponorogo dipilih secara purposive karena Kabupaten ini menjadi pilot project saat peluncuran PKH pertama kali di Indonesia pada 2007. Penelitian ini merupakan penelitian deskriptif dengan dukungan data kualitatif. Informan dipilih secara purposive pada pelaksana dan peserta PKH. Data penelitian ini dikumpulkan melalui wawancara mendalam, dokumentasi dan observasi. Validitas data menggunakan metode triangulasi. Sedangkan metode evaluasi yang digunakan adalah single program before afterdengan menggunakan analisis kerangka pemberdayaan Longwe. Hasil penelitian menunjukkan bahwa meskipun implementasi PKH telah mampu menambah tingkat kesejahteraan pesertanya, meningkatkan akses dan kehadiran di sekolah dan layanan kesehatan, memberikan penyadaran adanya diskriminasi gender, meningkatkan partisipasi terhadap program, namun PKH belum sepenuhnya menyentuh tingkat kontrol peserta terhadap lembaga pendidikan dan kesehatan ketika bersinggungan dengan kebutuhannya berdasarkan pilihan-pilihan aspirasi personalnya.
\end{abstract}

Kata kunci: penanggulangan kemiskinan, PKH, Kerangka Pemberdayaan Longwe, keberdayaan perempuan

\begin{abstract}
This study discusses the implementation and efforts to increase the empowerment of women by the Program Keluarga Harapan (PKH) as one of the poverty reduction program in Ponorogo District, East Java Indonesia. Ponorogo were selected purposively for this district became a pilot project during the launch PKH first in Indonesia in 2007. This study is a descriptive with qualitative data support. Informants were selected purposively on implementers and participants $\mathrm{PKH}$. The research data were collected through interviews, documentation and observation. The validity of the data using triangulation method. For evaluation method using a single program before after with analysis of Longwe'sempowerment framework. The results showed that although the implementation of the CCT has been able to increase the welfare of the participants, improving access to and
\end{abstract}


attendance at schools and health care, to raise awareness of discrimination of gender, to increase participation in the program, but PKH has not fully increased control levels of participants to health and educational institutions when meet to their needs based on their personal aspirations.

Keyword: poverty reduction, PKH, Longwe's Framework Empowerment, Women Empowerment

\section{A. Pendahuluan}

Kemiskinan bersifat multidimensi dan merupakan persoalan kompleks yang terkait dengan berbagai dimensi yakni sosial, ekonomi, budaya, politik serta dimensi ruang dan waktu. Kemiskinan didefinisikan sebagai kondisi seseorang atau sekelompok orang, laki-laki dan perempuan, tidak terpenuhi hak-hak dasarnya untuk mempertahankan dan mengembangkan kehidupan yang layak (BAPPENAS.2005).

Meskipun situasi kemiskinan dapat terjadi pada siapa saja, baik laki-laki maupun perempuan, Darwin (2005:164) menegaskan bahwa penerapan perspektif gender dalam melihat kemiskinan tidak berarti mengecilkan arti kemiskinan yang dialami laki-laki, tetapi untuk menegaskan bahwa kemiskinan yang dialami perempuan bersifat spesifik, sehingga kemiskinan perempuan yang bersifat spesifik ini membutuhkan penanganan yang bersifat khusus pula.

Berangkat dari kenyataan tentang relasi gender yang melemahkan posisi perempuan, diperlukan kebijakan, strategi, dan program yang bersifat afirmatif yang bertujuan memberdayakan perempuan dalam aspek apapun yang akan memberi kontribusi penting untuk kesetaraan gender (Mawardi,2013:19).
Karena itu, upaya penanggulangan masalah kemiskinan tidak dapat dilepaskan dari perhatian terhadap perempuan dan pemberdayaan perempuan harus menjadi prioritas program. Salah satu jenis program penanggulangan kemiskinan yang telah dipraktekkan di berbagai negara dikenal dengan Conditional Cash Transfer (CCT). CCT adalah jenis program yang memberikan bantuan tunai kepada kelompok miskin dengan kewajiban tertentu yang harus dipenuhi (Doetinchem,2008).

Soares (2010) menyatakan bahwa CCT memiliki tujuan ganda, yakni mengentaskan kemiskinan dalam jangka pendek, melalui transfer, dan mencegah terjadinya rantai kemiskinan antar generasi dalam jangka panjang, melalui investasi yang diperlukan dalam modal manusia melalui peningkatan dimensi pendidikan, kesehatan dan gizi. Program CCT di Mexico telah berhasil menunjukkan pengurangan substansial dalam kemiskinan. Efek pengurangan ini terlihat pada menurunnya ukuran kesenjangan kemiskinan dan tingkat keparahan kemiskinan (Skoufias 2008).

Di Bangladesh, putus sekolah menyebabkan anak-anak menuju ekslusi sosial berada pada lapisan bawah. Praktek CCT telah berhasil mengembalikan anakanak putus sekolah yang jumlahnya sangat 
besar dengan memberikan bantuan tunai kepada anak-anak miskin. Pengalaman Bangladesh juga menunjukkan bahwa CCT membalik hirarki gender dalam pendidikan dasar. Ada lebih banyak anak perempuan dari warga miskin yang bersekolah ketimbang anak laki-laki (Hossain,2010).

Tahun 2005 India menjalankan CCT yang bertujuan meningkatkan akses layanan kesehatan anak dan reproduksi. Penelitian Carvalho (2014) menemukan bahwa program ini meningkatkan imunisasi dari 3,1 persen menjadi 9,1 persen dalam proporsi penuh anak divaksinasi. Ia juga menemukan bahwa CCT di India telah menyebabkan peningkatan perilaku sehat sejak dini dan pemberian ASI setelah melahirkan.

Pengalaman di Amerika Latin, penerima dana transfer program CCT adalah perempuan. Alasannya karena perempuan atau ibu bertanggung jawab terhadap anakanak dalam rumah tangga, dan bahwa uang yang diterima perempuan lebih terkonsentrasi dibelanjakan untuk kesejahteraan anak-anak (Nagels,2013). Menurut Nagels (2013), program CCT ini telah memiliki efek memberdayakan perempuan. "...some quantitative and qualitative evaluations have claimed that the programmes have had an empowering effect on women. Fakta bahwa program ini memungkinkan wanita memiliki kontrol atas penghasilan tetap, bahkan meskipun dalam jumlah yang relatif kecil, telah menyebabkan peningkatan posisi tawar dan kepercayaan diri perempuan dalam rumah tangga.

Slater (2011) menyatakan bahwa hampir semua tujuan utama bantuan tunai adalah mengaktifkan konsumsi rumah tangga yakni kebutuhan dasar, khususnya pangan. Termasuk bantuan sosial seperti pensiun sosial untuk orang tua, penyandang cacat dan janda serta tunjangan untuk penyandang HIV/AIDS, anak yatim dan bantuan insentif upah kerja untuk rumah tangga miskin.

Meskipun terdapat perbedaan dalam desain khusus setiap program, namun Glassman (2013) menyatakan bahwa program CCT biasanya memiliki fitur kunci sebagai berikut:

a. Transfer tunai yang dikondisikan pada pemanfaatan layanan kesehatan, pendidikan, dan gizi

b. upaya informasi kesehatan, pendidikan dan komunikasi

c. Identifikasi ex-ante (penargetan) dari kelompok masyarakat penerima atau rumah tangga, dengan menggunakan beberapa kriteria

d. Verifikasi sesuai dengan kondisi yang disyaratkan.

Di Indonesia, program CCT ini dikenal dengan Program Keluarga Harapan (PKH). Program ini memberikan bantuan tunai kepada keluarga miskin dengan syarat memenuhi kewajiban dalam pendidikan dan kesehatan. Program ini diluncurkan pertama kali pada tahun 2007 meliputi 48 Kabupaten di tujuh Provinsi. Di Jawa Timur, Kabupaten Ponorogo termasuk salah satu Kabupaten yang menjadi pelaksana PKH sejak pertama kali diluncurkan tahun 2007.

Kerangka Pemberdayaan Perempuan (Women's Empowerment Framework) dimunculkan pada tahun 1990 oleh Sara H. Longwe (Sahay,1998:39). Kerangka ini 
digunakan untuk mengetahui kesetaraan dan pemberdayaan perempuan dan menilai sejauh mana intervensi sebuah program telah mendukung pemberdayaan. Longwe mendefinisikan pemberdayaan perempuan sebagai memungkinkan perempuan mengambil posisi yang setara dengan lakilaki dan berpartisipasi dalam proses pembangunan dalam rangka mencapai kontrol atas faktor-faktor produksi atas dasar kesetaraan dengan laki-laki. Pembangunan adalah menjadikan seseorang bertanggung jawab atas kehidupan mereka sendiri dan melepaskan diri dari kemiskinan. Menurutnya, kemiskinan muncul bukan karena kurangnya produktivitas, melainkan akibat penindasan dan eksploitasi (March, 1999:92).

Pemberdayaan perempuan dapat dilihat dari lima tingkat kesetaraan. Tingkat kesetaraan ini dimulai dari yang paling rendah: kesejahteraan, akses, kesadaran, partisipasi, kontrol. Tingkat kesetaraan ini berada dalam hubungan hirarkis, sehingga kesetaraan kontrol lebih penting ketimbang kesetaraan kesejahteraan. Tingkat kesetaraan yang lebih tinggi menunjukkan tingkat pembangunan dan pemberdayaan yang lebih tinggi.

\section{Bagan 1 Tingkat Kesetaraan Longwe}

$$
\text { Bagan }
$$

Tingkat Kesetaraan Longwe

Kontrol

Partisipasi

Kesadaran

Akses

Kesejahteraan

Kesejahteraan merujuk pada kebutuhan dasar. Akses merujuk pada kemampuan untuk menggunakan sumber daya seperti kredit, tanah dan pendidikan. Penyadaran merupakan elemen kunci dari kerangka ini: pengakuan bahwa diskriminasi menimbulkan masalah berkaitan dengan gender. Dengan partisipasi, perempuan setara dengan laki-laki dalam pengambilan keputusan, dan dengan kontrol keseimbangan kekuasaan antara laki-laki dan perempuan adalah setara. (Sahay,1998:39-40 \& Sweetman,1997:29).

Untuk melihat implementasi PKH sebagai salah satu kebijakan penanggulangan kemiskinan, tulisan ini membatasi pada dimensi pencapaian tujuan (Lester\&Stewart Jr, 2000; Grindle,1980), komunikasi (Meter dan Horn, 1975; Edward III,1980), dan disposisi pelaksana (Meter\&Horn,1975; $\quad$ Grindle,1980). Berdasarkan uraian di atas, tulisan ini untuk mengetahui: (1). Bagaimana implementasi PKH di Kabupaten Ponorogo; dan (2). Apakah PKH telah meningkatkan keberdayaan Perempuan Peserta PKH.

\section{B. Metode Penelitian}

Kabupaten Ponorogo dipilih secara purposive karena Kabupaten ini menjadi pilot project saat peluncuran $\mathrm{PKH}$ pertama kali di Indonesia pada 2007. Penelitian ini merupakan penelitian deskriptif dengan dukungan data kualitatif. Informan dipilih secara purposive pada Pelaksana dan Perempuan Peserta PKH. Data penelitian ini dikumpulkan melalui wawancara mendalam, dokumentasi dan observasi. Validitas data menggunakan metode triangulasi. Sedangkan metode evaluasi yang digunakan adalah single program before after (Wibawa, 1994:74-75) dengan menggunakan analisis kerangka 
pemberdayaan perempuan Longwe (Sahay,1998 dan Sweetman,1997).

\section{Hasil dan Pembahasan}

Tahun 2007, Kabupaten Ponorogo mendapatkan program ini. Awalnya, hanya delapan dari 21 Kecamatan yang menerima program ini dengan total penerima 4.251 peserta. Seluruh peserta didampingi oleh petugas Pendamping sebanyak 15 orang pada awalnya.

Hingga tahun 2014, pengembangan $\mathrm{PKH}$ telah mencakup seluruh Kecamatan di Kabupaten Ponorogo yang berjumlah 21 Kecamatan. Pada tahun akhir tahun 2015, Tahap IV, penerima bantuan PKH di Kabupaten Ponorogo sebanyak 12.708 Peserta dengan total Petugas Pendamping sebanyak 61 orang.

\section{Implementasi PKH}

Tujuan utama PKH adalah mengurangi kemiskinan dan meningkatkan kualitas sumberdaya manusia terutama pada kelompok masyarakat miskin. Dan secara khusus PKH bertujuan: (a.)Meningkatkan status sosial ekonomi peserta, (b.)Meningkatkan status kesehatan dan gizi ibu hamil, ibu nifas, anak balita dan anak usia 5-7 tahun yang belum masuk sekolah dasar, (c.)Meningkatkan akses dan kualitas pelayanan pendidikan dan kesehatan, khususnya bagi anak-anak PESERTA, (d.)Meningkatkan taraf pendidikan anak-anak Peserta (Kementerian Sosial RI:2009).

Dalam peningkatan status sosial ekonomi, pada tahun 2013 telah dilakukan proses resertifikasi pada peserta yang menerima bantuan sejak tahun 2007 di delapan kecamatan. Resertifikasi yang dilakukan oleh lembaga di luar PKH ini mengukur tingkat kesejahteraan dan status sosial ekonomi. Hasilnya didapatkan 1.243 dari 4.521 peserta $\mathrm{PKH}$ dikategorikan sebagai graduasi. Kategori ini menilai bahwa sejumlah peserta tersebut telah dalam kondisi yang bukan lagi keluarga sangat miskin sehingga tidak lagi memenuhi persyaratan PKH. Dengan kata lain, berdasarkan indikator resertifikasi tersebut dinyatakan bahwa para peserta PKH telah meningkat kesejahteraannya.

Pada pencapaian tujuan peningkatan status kesehatan, gizi untuk ibu hamil dan balita, serta akses terhadap layanan pendidikan dan kesehatan, PKH telah memastikan pesertanya hadir pada layanan pendidikan dan kesehatan minimal $85 \%$ kehadiran dengan kewajiban menjalani protokol kesehatan yang disyaratkan. Pada tahap I tahun 2012, diketahui hanya sekitar 33 peserta yang mendapatkan sanksi pemotongan karena tidak memenuhi kewajiban atau kehadirannya kurang dari $85 \%$ seperti yang disyaratkan oleh PKH.

Jika implementasi dilihat dari sisi proses, maka tujuan program PKH telah dilaksanakan. Mulai dari pendataan dan validasi peserta, pemutakhiran data, proses verifikasi dan penyaluran bantuan. Sedangkan dari sisi output, yakni hasil yang diinginkan berdasarkan tujuan-tujuan khusus PKH, meskipun belum seratus persen dicapai, setidaknya PKH di Kabupaten Ponorogo telah mampu meningkatkan status kesehatan, taraf pendidikan dan akses terhadap layanan kesehatan dan pendidikan sebagaimana tujuan yang ingin dicapai PKH.

Keberhasilan implementasi kebijakan mensyaratkan pelaksana mengetahui apa yang harus dilakukan. Tujuan kebijakan 
harus ditransmisikan dan dikomunikasikan kepada kelompok sasaran dengan tepat, akurat, dan konsisten (Edward III, 1980:17). Meningkatnya motivasi dan kehadiran Peserta pada layanan pendidikan dan kesehatan yang mencapai lebih dari $85 \%$ pada hasil verifikasi kehadiran menunjukkan bahwa salah satu tujuan kebijakan PKH telah tersampaikan kepada peserta.

Sejalan dengan pendapat Umar (2008:4244), bahwa PKH Kabupaten Ponorogo telah melakukan komunikasi yang dapat dilihat dari dua sisi, yakni komunikasi antarpribadi dan komunikasi organisasi.

Komunikasi antar pribadi pelaksana $\mathrm{PKH}$ yakni Pendamping dan Operator dilakukan cukup terbuka, terdapat empati, saling mendukung, dan memiliki aspek kesamaan berupa kesadaran menjalankan tugas yang sama. Sedangkan dalam komunikasi organisasi dari atas ke bawah dan sebaliknya, berupa perintah atau laporan, berjalan dengan mekanisme formal surat menyurat resmi yang didukung penggunaan media sosial yang cenderung informal tetapi cukup efektif.

Implementasi sebuah kebijakan dapat berjalan dengan efektif tidak hanya memerlukan pemahaman dan kemampuan tentang apa yang akan dilakukan pelaksana, namun diperlukan juga kemauan dari pelaksananya terhadap kebijakan tersebut. Demikian pula dengan PKH, sebagai sebuah kebijakan yang harus diimplementasikan secara efektif sampai ke target group, implementasi $\mathrm{PKH}$ memerlukan dukungan dari pelaksana. Bentuk dukungan ini berupa sikap pelaksana (dispostions) yakni pemahaman dan kemauan pelaksana untuk melaksanakan kebijakan tersebut.

\section{Peningkatan Keberdayaan Perempuan Peserta PKH}

a. Tingkat Kesejahteraan

Tingkat ini merujuk pada kesejahteraan secara material dan manfaat terhadap pemenuhan kebutuhan pendidikan dan kesehatan bagi peserta. Di Kabupaten Ponorogo, PKH telah menyalurkan bantuan sebesar Rp. 22.012.432.500 hingga tahun 2015 kepada 12.834 peserta. Bantuan ini diterimakan kepada peserta empat tahap dalam setahun yang berbeda besarannya tergantung pada jumlah anggota tangganya yang menjadi komponen PKH. Beberapa wawancara menunjukkan bahwa para Peserta merasakan perbedaan setelah menerima bantuan PKH. Menurut mereka, bantuan ini sangat membantu dalam pemenuhan biaya-biaya sekolah dan peningkatan gizi untuk balita mereka. Manfaat dalam menunjang pendidikan dinyatakan oleh peserta PKH berikut ini:

...damel mbayar SPP, biaya kegiatan sekolah, buku, kemarin dua ratus ribu untuk buku langsung dianggarne ke situ.. Nggih beda setelah ada PKH, sangat membantu buat biaya sekolah, buat sangu, buat beli susu anake..nggih seneng pak, apalagi saya yang nggak punya suami, bantuan PKH niki sangat membantu.. (Wawancara, 31 Oktober 2015, Kec.Kauman)

Sedangkan manfaat bantuan dalam kesehatan dan anak balitanya, salah satu peserta menyatakan sebagai berikut:

...damel tumbas perlengkapan bayi, yo sabun, yo bedak, yo ngoten niku.. 
nggih nambah pemasukan ngoten.. alhamdulillah... (untuk membeli perlengkapan bayi, ya sabun, ya bedak, ya gitu itu. iya, menambah pemasukan gitu,.. alhamdulillah..) (Wawancara, $31 \quad$ Oktober 2015,Kec.Kauman)

Menurut Peserta PKH, dengan bantuan yang diterima menambah kemampuan mereka untuk membeli makanan bergizi bagi ibu hamil dan perlengkapan balita. Sedangkan dalam pendidikan, mereka terbantu dalam pembelian peralatan sekolah, seperti tas, sepatu, seragam sekolah. Termasuk biaya transportasi bagi yang sekolahnya jauh dari rumah.

Dibandingkan sebelum adanya PKH, terdapat perubahan dan peningkatan kesejahteraan yang bersifat materi dalam status gizi, persediaan makanan dan pendapatan yang langsung dipegang oleh perempuan. Meskipun, menurut Longwe, tingkat kesejahteraan ini berada pada tingkat terendah pemberdayaan, namun tanpa keamanan materi dasar sulit bagi mereka untuk melangkah naik pada tingkatan pemberdayaan berikutnya.

b. Tingkat akses terhadap layanan pendidikan dan kesehatan

Salah satu tujuan $\mathrm{PKH}$ adalah meningkatkan akses dan kualitas pelayanan pendidikan dan kesehatan bagi pesertanya. Kewajiban inilah yang menjadi inti dari program CCT. Berdasarkan catatan daftar kehadiran beberapa layanan posyandu tidak ditemukan peningkatan yang signifikan terhadap kehadiran pada layanan ini sebelum dan sesudah adanya PKH. Menurut Pendamping di Kecamatan Kauman dan Ngrayun, karena sebelum adanya $\mathrm{PKH}$ tingkat kehadiran di posyandu sudah cukup tinggi. Ajakan dan dorongan telah dilakukan oleh Perangkat Desa, Bidan maupun Kader Posyandu kepada para Ibu balita baik kepada peserta PKH maupun non-PKH.

Meskipun tidak ditemukan perubahan signifikan pada kehadiran di layanan Posyandu, namun PKH telah memberikan kepastian dengan mengharuskan pesertanya memanfaatkan layanan kesehatan sebagai kewajiban yang harus dipenuhi. Jika tidak, maka bantuannya akan dipotong bahkan diberhentikan sebagai peserta. Sanksi inilah yang menjadi ciri khas dari program jenis CCT yang memaksa kelompok sasaran program untuk memenuhi kewajiban yang disyaratkan.

Data UPPKH Kabupaten Ponorogo pada tahap I tahun 2012 menunjukkan bahwa 33 dari 7.756 atau sekitar $0,4 \%$ Peserta yang mendapatkan sanksi pemotongan karena tidak memenuhi kewajiban atau kehadirannya di sekolah dan layanan kesehatan. Berkaitan dengan peran tradisional perempuan sebagai pengasuh anak, PKH memaksa diri Peserta dan anak-anaknya untuk mengakses layanan pendidikan dan kesehatan. Pada proses perjalanan selanjutnya, melalui strategi FDS (family development session) $\mathrm{PKH}$ memberikan penyadaran kepada peserta tentang manajemen pengasuhan anak, baik dalam hal pendidikan dan kesehatan, tidak hanya dilakukan oleh perempuan tetapi juga menjadi tanggung jawab laki-laki.

c. Tingkat penyadaran

Tingkat penyadaran melihat pada cakupan keyakinan bahwa pembagian kerja antara 
laki-laki dan perempuan harus adil, tidak terdapat dominasi salah satu jenis kelamin. Keyakinan persamaan ini terletak pada landasan kesadaran gender dan memberikan landasan partisipasi kolektif antara laki-laki dan perempuan. Dasar dari kesadaran ini diawali dari pemahaman dan peka terhadap diskriminasi. Diskriminasi bahwa perempuan lebih rendah status sosialnya dibandingkan laki-laki.

Strategi FDS (Family Development Session) yang diberikan kepada perempuan peserta PKH bertujuan di antaranya sebagai upaya penyadaran tentang adanya diskriminasi. Misalnya dalam materi pengasuhan anak. Pendamping memberikan sosialisi tentang peran ini yang tidak hanya menjadi tugas ibu atau perempuan saja, melainkan juga peran suami. Strategi ini tidak hanya diberikan perempuan saja, selain itu Pendamping juga melakukan sosialisasi kepada suami peserta PKH tentang kewajiban dan tanggung jawab suami pada tugas-tugas domestik. Upaya ini dilakukan untuk memunculkan kesadaran bersama antara laki-laki dan perempuan dalam manajemen rumah tangga. Dengan penyadaran ini diharapkan bisa mengurangi beban kerja akibat peran tradisional yang selama ini melekat pada perempuan.

Sedangkan dalam hal penggunaan uang bantuan, telah disepakati oleh suami istri bahwa penggunaanya adalah untuk memenuhi kebutuhan gizi dan keperluan sekolah. Ketika ditanya apakah suami pernah meminta uang untuk keperluan suaminya, salah seorang perempuan peserta PKH mengatakan sebagai berikut: ...mboten pernah pak nek suami saya.. nopo malih dijaluk, gak boleh pak...soale ngerti pak, suami saya niki ngerti kalau dapat niki untuk anak, bukan kok untuk saya atau suami saya.. (Tidak pernah pak suami saya.. apalagi diminta, tidak boleh pak, soalnya tahu pak, suami saya mengerti kalau dapat $-\mathrm{PKH}$ ini untuk anak, bukan untuk saya atau suami saya). (Wawancara, 30 Oktober 2015)

Uang bantuan PKH yang diterimakan kepada perempuan ini, sebagaimana dikatakan Nagels (2013), membuat perempuan memiliki kontrol atas penghasilan, bahkan meningkatkan posisi tawar dan kepercayaan diri perempuan dalam rumah tangga meskipun jumlahnya relatif kecil. Selain itu, strategi FDS telah memberikan kepekaan bahwa terdapat diskriminasi peran antara perempuan dan laki-laki di dalam rumah tangga. Namun, sayangnya pada 2015, strategi FDS ini belum diberikan kepada seluruh peserta PKH sebatas peserta tahun 2007 di empat Kecamatan.

d. Tingkat partisipasi Peserta pada Layanan Pendidikan dan Kesehatan

Peran peserta PKH dalam penilaian kebutuhan mereka dalam dimensi pendidikan dan kesehatan, seperti pada rapat wali murid, posyandu, forum kelompok ibu-ibu peserta PKH, terdapat perbedaan setelah mereka menjadi peserta PKH. Contohnya, ketika di posyandu ada pemberian Vitamin A atau tetes Polio, sebelumnya mereka diam saja pasrah menerima. Namun setelah menjadi peserta PKH, ada keberanian untuk bertanya kepada bidan atau kader posyandu tentang 
apa yang diberikan, seperti jenis vitamin atau imunisasi apa yang akan diberikan. Pemahaman tentang hak-hak ini karena mereka diwajibkan hadir pada pertemuan kelompok kemudian diberikan sosialisasi tentang protokol layanan kesehatan dasar sehingga peserta PKH menjadi faham tentang apa yang harus mereka terima. (Wawancara, 19 Februari 2016).

\section{e. Tingkat Kontrol.}

Pemberdayaan pada tingkat ini memuat dua pengertian kunci yakni kekuasan dan kelompok lemah. Keseimbangan antara perempuan peserta $\mathrm{PKH}$ dengan pihak sekolah, puskesmas atau bidan posyandu ketika berkaitan dengan kebutuhan mereka. Persamaan atau keseimbangan kontrol berarti tidak adanya dominasi oleh salah satu pihak.

Meskipun sudah muncul keberanian atau inisiatif untuk bertanya, usul, dan meminta penjelasan, sebagaimana dijelaskan sebelumnya pada tingkat partisisipasi, namun Perempuan Peserta PKH belum memiliki kekuatan atau power untuk mengubah suatu keputusan yang menyangkut dirinya. Misalnya, pada forum wali murid yang memutuskan tentang biaya-biaya yang harus dibayarkan, para wali murid peserta PKH hanya sebatas pada berani bertanya dan meminta penjelasan. Mereka tidak memiliki kekuatan untuk mengubah keputusan itu. Meskipun keberatan dengan besarnya jumlah biaya, mereka hanya menerima keputusan. (wawancara 25 Februari 2016).

Peserta PKH belum mampu mempengaruhi pranata masyarakat seperti lembaga pendidikan dan kesehatan, hal ini karena masih lemahnya nilai tawar mereka terhadap kekuasaan. Jika dilihat dari kerangka Longwe, implementasi PKH tidak menunjukkan pemberdayaan hingga ke tingkat kontrol. Pemberdayaan pada tingkat ini tidak menjadi tujuan program yang dinyatakan secara eksplisit. Padahal menurut Longwe, sebuah program pemberdayaan akan mencapai derajat tertinggi atau berhasil melakukan pemberdayaan apabila menyentuh pada tingkat kontrol.

Tabel 1 : Hasil Analisis Perubahan pada Aspek Keberdayaan Peserta PKH

Bidang Pendidikan

\begin{tabular}{lll}
\hline Tingkat & Sebelum PKH & Sesudah PKH \\
\hline \multirow{2}{*}{ Kontrol } & - Tidak ada & - Tidak ada \\
& - Cenderung pasif, tidak & - Hadir dalam pertemuan wali murid di sekolah \\
& ada keberanian dan & anaknya \\
& insiatif dalam pertemuan & - Adanya inisiatif bertanya, usul, tentang BSM, \\
& wali murid & penggunaan biaya dan iuran \\
& & - Bapak menemani anak belajar \\
& - Kurangnya kesadaran & - Bapak mengetahui penggunaan dana bantuan \\
& tentang tugas & PKH yang diterima ibu untuk keperluan \\
Penyadaran & pengasuhan anak & sekolah anaknya \\
& terutama oleh Bapak & - Bapak dan ibu bersama-sama melakukan \\
& & tugas pengasuhan anak
\end{tabular}




\begin{tabular}{|c|c|c|}
\hline Akses & $\begin{array}{l}\text { - Terdapat beberapa anak } \\
\text { yang putus sekolah dan } \\
\text { tidak melanjutkan } \\
\text { jenjang lebih tinggi } \\
\text { dengan alasan biaya, } \\
\text { jarak yang jauh. }\end{array}$ & $\begin{array}{l}\text { - kehadiran di sekolah mencapai minimal } 85 \% \\
\text { dengan adanya verifikasi kehadiran } \\
\text { - Terdapat anak putus sekolah yang kembali } \\
\text { bersekolah saat dinyatakan menjadi peserta } \\
\text { PKH }\end{array}$ \\
\hline Kesejahteraa & $\begin{array}{l}\text { - Kekurangan dana untuk } \\
\text { biaya keperluan sekolah }\end{array}$ & $\begin{array}{l}\text { - Terbantu membeli keperluan } \\
\text { sekolah:seragam,sepatu, buku, } \\
\text { - Terbantu membayar iuran sekolah } \\
\text { - Terbantu biaya transportasi }\end{array}$ \\
\hline
\end{tabular}

Sumber: Hasil analisis

Tabel 2. Hasil Analisis Perubahan pada Aspek Keberdayaan Perempuan Peserta PKH Bidang Kesehatan

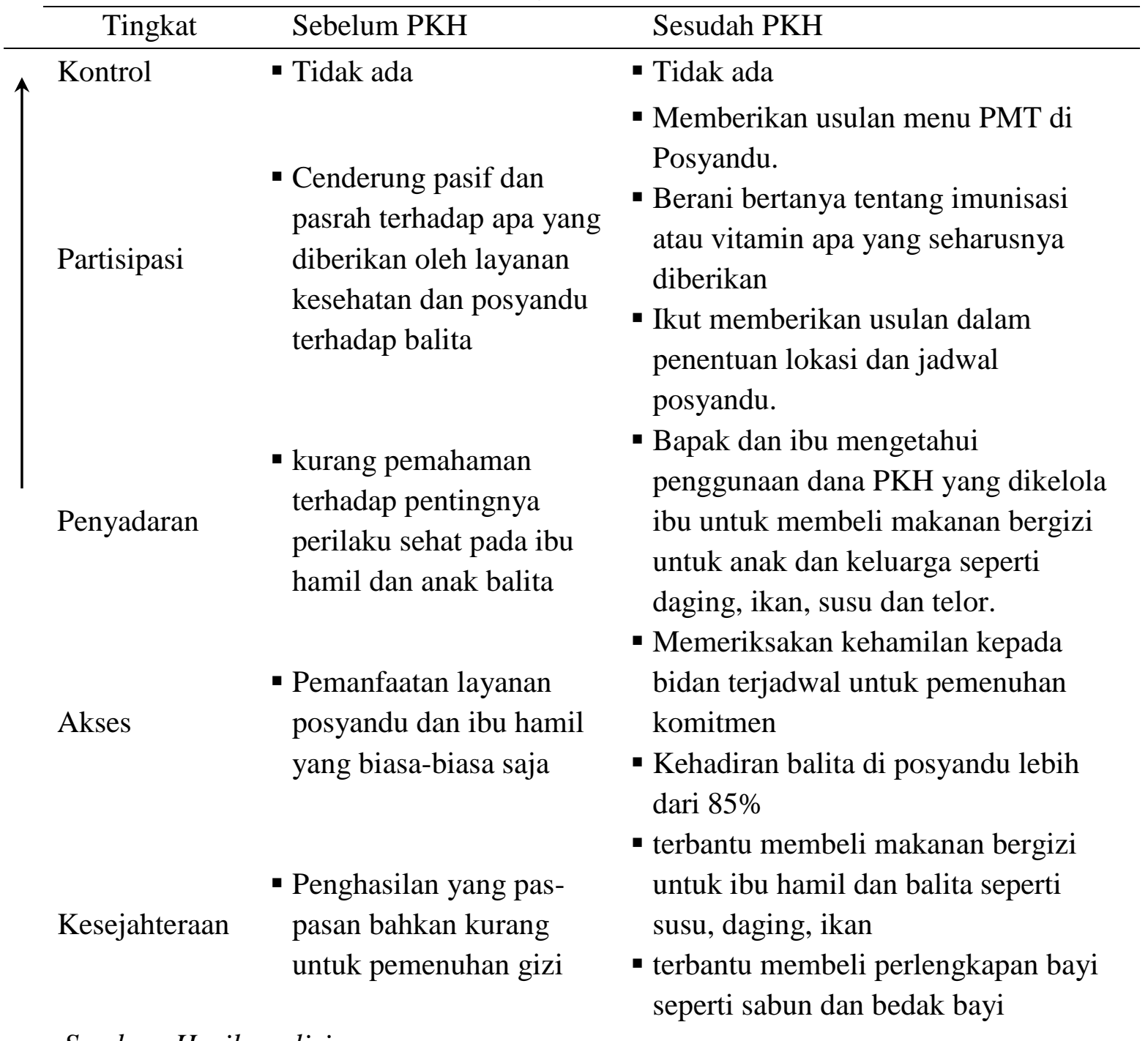




\section{Kesimpulan}

1. Implementasi $\mathrm{PKH}$ di Kabupaten Ponorogo diketahui telah memberikan tambahan penghasilan dan meningkatkan kesejahteraaan pesertanya. PKH juga memberikan kepastian terhadap kehadiran di sekolah dan layanan kesehatan sesuai dengan protokol yang ditentukan. Jika dilihat berdasarkan tujuannya, implementasi PKH telah mencapai tujuannya. Aspek implementasi yang mendukung pencapaian tujuan ini berupa komunikasi organisasi dan disposisi pelaksana $\mathrm{PKH}$ yang efektif dalam mengkomunikasikan tujuan program.

2. Dalam peningkatan pemberdayaan perempuan, diketahui PKH masih sampai pada empat tingkat, yakni kesejahteraan, akses, penyadaran dan partisipasi. Meskipun $\mathrm{PKH}$ telah menambah tingkat kesejahteraan pesertanya, meningkatkan akses dan kehadiran di sekolah dan layanan kesehatan, memberikan penyadaran adanya diskriminasi gender melalui strategi FDS, dan meningkatkan partisipasi Pesertanya pada forum wali murid dan layanan kesehatan, namun PKH belum menyentuh pemberdayaan tingkat kontrol yang merupakan level tertinggi dalam hirarki pemberdayaan Longwe.

3. Beberapa aspek pendukung keberhasilan di empat tingkat pemberdayaan dalam kerangka Longwe antara lain: bantuan tunai yang diberikan dan mekanisme verifikasi dan sanksi yang merupakan ciri khusus program CCT.

Pada tingkat penyadaran ditemukan hambatan yaitu belum dilaksanakan strategi FDS secara menyeluruh. Sedangkan tidak adanya pemberdayaan pada tingkat kontrol karena pemberdayaan pada tingkat ini tidak menjadi tujuan PKH.

\section{Daftar Pustaka}

BAPPENAS \& Komite Penanggulangan Kemiskinan. 2005. Strategi Nasional Penanggulangan Kemiskinan. Jakarta

Carvalho, N., Thacker, N., Gupta, S.S. and Salomon, J.A., 2014. More Evidence on the Impact of India's Conditional Cash Transfer Program, Janani Suraksha Yojana: Quasi-Experimental Evaluation of the Effects on Childhood Immunization and Other Reproductive and Child Health Outcomes. Journal of PLoS One,9(10), pp. e109311.

Darwin, Muhajir. 2005. Negara dan Perempuan: Reorientasi Kebijakan Publik, Yogyakarta: Media Wacana,

Doetinchem, Ole, $\mathrm{Ke} \mathrm{Xu}$, and Guy Carrin.2008. Conditional cash transfers: what's in it for health? . World Health Organization Geneva.

Edward III, George C. (1980). Implementing Public Policy, Washington DC: Congressional Quarterly Inc.

Glassman A, Duran D, Koblinsky M, et al. Impact of Conditional Cash Transfers on Maternal and Newborn Health. Journal Of Health, Population \& Nutrition. December 2, 2013;31:48-66.

Grindle, Merilee S., (ed), 1980, Politics and Apolicy Implementation in the Third World, New Jersey: Princetown University Press.

Hossain N.,2010. School Exclusion as Social Exclusion: the Practices and Effects of a Conditional Cash Transfer Programme for the Poor in Bangladesh. 
Journal Of Development Studies. August 2010;46(7):1264-1282.

Lester, James P., dan Joseph Stewart Jr. 2000. Public Polcy: An Evolutionary Approach. Belmont: Wadsworth

Kementerian Sosial RI.2009.Pedoman PKH 2009.Jakarta.

March, Candida, I. Smyth and M. Mukhopadhyay.1999. A Guide to Gender Analysis Frameworks, Oxford: Oxfam.

Mawardi, Sulton. 2013. Program Pemerintah Untuk Pemberdayaan Ekonomi Perempuan. SMERU Newsletter no. 34/2013

Meter, Donald Van, dan Carl Van Horn. 1975.The Policy Implementation Process: A Conceptual Framework dalam Administration and Society 6. London: Sage

Nagels, N. (2016). The Social Investment Perspective, Conditional Cash Transfer Programmes and the Welfare Mix: Peru and Bolivia. Social Policy and Society, $15(3)$, 479-493. doi:10.1017/S1474746416000105

Sahay, Sushama 1998. Women and Empowerment: Approaches and Strategies. New Delhi: Discovery Publishing House.

Skoufias E, Di Maro V. Conditional Cash Transfers, Adult Work Incentives, and Poverty. Journal Of Development Studies. August 2008;44(7):935-960.

Slater, R. Cash transfers, social protection and poverty reduction. International Journal of Social Welfare. 20, 3, 250259, July 2011. ISSN: 13696866.

Soares, Fábio Veras, and Elydia Silva. 2010. Conditional Cash Transfer Programmes And Gender Vulnerabilities: Case Studies Of Brazil, Chile And Colombia. International
Policy Centre for Inclusive Growth United Nations Development Programme

Sweetman, Caroline. 1997. Gender in development organisations. Oxfam GB.

Umar, Husein. 2008. Desain Penelitian MSDM dan Perilaku Karyawan, Paradigma Positivistik dan Berbasis Pemechan Masalah. Jakarta: Rajawali Pres.

Wibawa, Samodra. Purbokusumo, Yuyun dan Pramusinto, Agus.1994. Evaluasi Kebijakan Publik. Jakarta: PT Raja Grafindo Persada

World Bank. 2001. Empowerment and PovertyReduction - A Sourcebook. Washington DC: World Bank. 
Spirit Publik Volume 13, Nomor 1, April 2018

Halaman 67-78

P-ISSN. 1907-0489 E-ISSN 2580-3875 